\title{
UNVEILING THE CONTEMPORARY IN VIRGINIA WOOLF
}

\author{
Patricia Marouvo ${ }^{1}$
}

${ }^{1}$ Universidade Federal do Acre, Rio Branco, AC, Brasil

\begin{abstract}
This article aims to discuss Virginia Woolf's critical appraisal of the contemporariness of her contemporaries' production while also probing the very idea of what constitutes "the contemporary". "The Modern Essay (1921) serves as the frame for what Woolf dubbed "the contemporary dilemma", which this article then traces in "How it Strikes a Contemporary" (1923). Resorting to other major essays, this article contextualizes Woolf's publication of The Common Reader - First Series (1925) so as to explore its conversational quality as a philosophical principle inherent to Woolf's oeuvre (Pinho 2020). The philosophically inclined methodology of Woolf's essays finds fertile ground in Giorgio Agamben's "What Is the Contemporary?" (2009). Ultimately, by reading Woolf alongside Agamben, this article sheds light on the intersections between contemporary philosophy and the philosophical questions we continue to find in Woolf's writing.

Keywords: Virginia Woolf; essay; contemporary; philosophy
\end{abstract}

"Professor of English at Universidade Federal do Acre (UFAC). She holds a PhD in Comparative Literature (Universidade Federal do Rio de Janeiro, 2019). She is the author of the forthcoming book Uma poética hídrica em The Waves, de Virginia Woolf (Appris). She has published articles and book chapters on Virginia Woolf, developing a philosophical reading of the writer’s oeuvre. E-mail address: patriciamarouvo@yahoo.com.br . ORCID: https://orcid.org/0000-0001-5506-953X. 
In "The Modern Essay" (1921), Virginia Woolf dwells on the changes the essay as form seemed to undergo in her time and in typically Woolfian fashion reaches a tentative conclusion, resorting to imagery that defies even the most imaginative and sensitive of readers to make sense of the "contemporary dilemma" critics faced when writing an essay: "the lack of an obstinate conviction which lifts ephemeral sounds through the misty sphere of anybody's language to the land where there is a perpetual marriage, a perpetual union" (Woolf "The Modern Essay" 22). The dilemma thus posed, it appears that her contemporaries no longer held the conviction that allowed for the "ephemeral" to be lifted so that a perpetual union or marriage could take place linguistically through common language. The argument I want to sustain in this article is that the opposition inscribed in Woolf's dilemma is overcome via the androgynous turn, making way for the common life to unfold in multiple ways of feeling, perceiving and thinking both linguistically and performatively.

"The Modern Essay" concludes that a good essay must have this lasting quality about it, or in her words - "it must draw its curtain round us, but it must be a curtain that shuts us in, not out" (Woolf "The Modern Essay" 22). The modern essay is an attempt to remain relevant to her contemporaries in times of dramatic social, political, historical and artistic changes, best encapsulated in Woolf's famous assertion that "on or about December 1910 human character changed" (Woolf "Character in Fiction" 38) ${ }^{1}$ in reference to the dramatic shift in human relations along with changes in religion, conduct, politics and literature. Besides, I would add, the modern essay serves as testimony of times past to the critics and readers of the future and it arouses their sensibilities as well as minds in relation to what elements can be actualized, meaning being updated and taking part in our present reality. While the influence of tradition onto modernist writers is often revisited from T. S. Eliot's perspective in his seminal "Tradition and the Individual Talent" (1921), Jane Goldman (2005) reminds us that Woolf's critical response to Eliot's essay reframes the question. If we ponder upon the methodology Virginia Woolf employs in A Room of One's Own (1929), we can see from her selection of women writers in chapter 4, ranging from Aphra Behn to Jane Austen and then to the Brönte sisters, that her tradition supplements that of the mostly male canon to which Eliot alludes. Woolf's take on tradition provides an alternate perspective so as to include female characters and women writers, which allows her to include the voices of the silenced others in the world, but also more specifically, British literary tradition².

If the imagery of the curtain at the very end of "The Modern Essay" could be associated with the intimacy established between the essay and its readership, it is also suggestive of an immersion in the experience of reading that envelops common readers, breaking down hierarchies and validating what is communal. Hermione Lee in "Virginia Woolf's Essays" (2010) provides a bird's eye view of Woolf's rather comprehensive essayistic production, emphasizing her struggle against editorial pressures and a self-consciousness of writing as a woman in a male tradition. Lee's contention that Woolf's non-fiction was "deliberately written 
to be accessible, entertaining and uncondescending for the varied audience of non-specialist general readers she wished to identify with" (Lee 91) may be said to summarize Woolf's wishes to a certain extent, though passages like the one mentioned above prove otherwise. In fact, I would agree that 'the essays' wandering structures, their 'speculative and hesitant' refusals to lay down the law" (Lee 91) is what helps to "create a form of subversion" (Lee 91).

While her conversational style does have a political quality to it, I would like to focus on its philosophical dimensions, referring to Davi Pinho's " $A$ conversa como um método filosófico em Virginia Woolf" (2020). In reference to Woolf's diary - "Shall I ever 'write' again? And what is writing? The perpetual converse I keep up" (Woolf The Diary of Virginia Woolf 57) -, Pinho (2020) suggests that her attempt to engage in a "perpetual converse", be it with her contemporaries or with writers of the past, could be interpreted as an exchange with empirical others at first, but perhaps it could also point to what is contrary in these others, to whatever opposes or even contradicts her ideas, meaning that conversation is fundamentally a way of coexisting with what is contradictory in a common playground. Pinho (2020) adds that this method could already be witnessed in Woolf's Night and Day (1919) in reference to Katharine Hilbery's cousins, something the Brazilian critic picks up by reading in the gaps of Julia Briggs. In this novel her cousins act as counterpoint to Katharine, asking her questions to incite a curiosity and a desire to know things previously unknown. This instigates her to have both "real and imaginary conversations with her cousins, especially with Henry Otway, serving to mediate her own limitations so as to overcome their understanding as well as her own" (Pinho 12-13) - hence Woolf terming this continuous interaction as "Otway conversations".

In fact, The Common Reader - First Series (1925) was envisaged as a collection of essays whose method would follow suit both in structure and in spirit. Andrew McNeillie (2003) points out that Woolf's intent was to "share something of the immediacy, the flashing brilliance and unscholarliness of conversation in which (invariably unidentified) quotations are capped and a dinner-table intimacy is assumed" (McNeillie ix). Moreover, McNeillie (2003) adds that Woolf mixes something of the serious novelist and the seasoned reviewer with the educational outsider, not having been granted access to formal education as freely as her male siblings. This resulted in an uncanonical reading of literary tradition, which ranges from antiquity to the beginning of the twentieth century, mostly focusing on British literature but also investigating Greek, French and Russian literature. It also allowed for communal readings of the classics to be endeavored by anyone who shared a passion for reading stories and for reflecting on how its effects on human experience can be interpreted symbolically - so much so that eminent figures in literary tradition are often treated as characters and, to a certain degree, her fictional characters translate much of the texture of life in Woolf's supplementing history. Language is at the center of many of the questions raised, meaning language and the worlds that writers, readers and critics come to inhabit is what Woolf enquires into the creation of stories. 
More specifically, Virginia Woolf’s "How it Strikes a Contemporary" (1923) contemplates the difficulties that lie in assessing one's own contemporaries' works with any degree of certainty without chronological or emotional distance, both of which seem to render classics with unequivocal density and importance. It seems that the writers of the past were better equipped to create a world whose tenacity would not break, because of an underlying stability that they possessed when creating their worlds and the laws that governed them. When referencing the works of William Wordsworth, Walter Scott or Jane Austen, Woolf comments on their ability to imagine different realities and so to use language to support and delineate characters, settings and ideas that invest their writing with the texture of human life and experience. Be it reader or critic, she states that "we feel ourselves indeed driven to them, impelled not by calm judgement but by some imperious need to anchor our instability upon their security" (Woolf "How it Strikes a Contemporary" 28).

It is because they believed so fiercely in the worlds they created that their readers can inhabit those pages just as well, they too believing in the opinions and values of those characters that at first might have seemed unrelatable. Wordsworth, Scott and Austen were able to anchor their worlds in the understanding that commonality could be a point of connection with others, but that it could also allow for experiencing other viewpoints than one's own - or in Woolf's words it could be said that "to believe that your impressions hold good for others is to be released from the cramp and confinement of personality" (Woolf "How it Strikes a Contemporary" 29). On the other hand, Woolf's contemporaries, she argues, make the most of the sensory opportunities that are made available to them, converging towards something that appears to render the experience whole. And yet, they remain unsuccessful, missing the mark and leaving their readers with the feeling of senselessness. In an age of fragments, it would appear that no solution could allow for an escape of one's own personality, and that Woolf's appreciation of the works of her predecessors sounds borderline nostalgic. It seems that those fragments cannot depict the sense of something attainable as a whole, not even as a mosaic, because of a lack of unity that holds the center of something only hinted at in their scraps of paper, but never fulfilled.

A parallel could be drawn between Woolf's essays and Giorgio Agamben's "What is the Contemporary?" (2009), helping to shed light on Woolf's philosophical methodology. Agamben's essay signals the impossibility of attaining the present moment if not through an estrangement derived from not completely belonging to one's own time. He proposes that "those who are truly contemporary, who truly belong to their time, are those who neither perfectly coincide with it nor adjust themselves to its demands" (Agamben "What is the Contemporary?" 40). And it is because of this condition of both belonging and unbelonging, of being immersed in the present without fully accepting and embracing it, it is because of this disconnection, this out-of-jointness that they can perceive and grasp their own time in an untimely manner, without resorting to any form of nostalgia or escapism. This untimely manner disrupts any sense of chronological 
or teleological development, remaining a dys-chrony whose significance emerges as the unsolicited, yet present.

It could be that the verb "strike" in "How it Strikes a Contemporary" also suggests this out-of-jointness. If more directly the word "strike" unfolds possibilities of understanding the numerous ways in which life can be perceived by contemporaries, it could be argued that it also signals a rupture, a break with the past - time is broken down into parts whose rearrangement can resignify the past and bring it closer to the present moment. The moment one feels the estrangement brought about by some only apparently solid remark, they are overcome with a pressing need to compare themselves with those who lived before them so that this comparison can offer alternatives and help to envision other ways of responding, even if common sense would not deem those investigative excursions reasonable, since they would not conform to current expectations. This essay in particular leaves readers feeling struck that no consensus can be reached on the merits of a work written by a contemporary. Woolf sets upon herself the task of enquiring into the helplessness common readers must feel as she fictionalizes a conversation taking place at a table where critics, novelists and poets endeavor to discuss their presentday literature. It is perhaps in the exercise of turning to classics that a comparison can help to make sense of the path thus opened to contemporaries, allowing for the evaluation of the opportunities taken and the possibilities dismissed, which should inform the status of contemporary aesthetics and politics.

Perhaps Agamben's conceptualization of the untimely could be compared to what Virginia Woolf coined as moments of being in her "A Sketch of the Past" (1939-1940), in which she proposes that some instances in life can radically change our perception of reality because they seem to intensify human existence in its revealing intimacy with their surroundings, enabling human beings to fulfill their potential of passionate reflection and connection with themselves and the world they create even if just for one moment. The moment emerges and in itself makes an exigency to which we cannot not respond, and so, if we are not instantly presented with the opportunity to make sense of the whole experience, it does not mean we are any less contemporary of our own individual lives.

Reading "A Sketch of the Past", along with Agamben's "What is the Contemporary?", I propose that there is a part within the present moment that we simply cannot live, either due to its traumatic nature or its excessive nearness. This means that, even if living in the present, a true contemporary understands that the present moment escapes from a complete and thorough experience, because there will always be gaps which make it just as evasive as the past, always resurfacing as new when re-interpreted, or the future, predictive by nature. For this reason, Agamben contends that "the contemporary is the one who, dividing and interpolating time, is capable of transforming it and putting it in relation with other times" (Agamben "What is the Contemporary?" 53). Still in "A Sketch of the Past", when describing the effects of three instances of exceptional moments (two of despair and one of intense satisfaction), Woolf equates the ability to receive these shocks and later explains them with what makes her a writer: 
I feel that I have had a blow; but it is not, as I thought as a child, simply a blow from an enemy hidden behind the cotton wool of daily life; it is or will become a revelation of some order; it is a token of some real thing behind appearances; and I make it real by putting it into words. It is only by putting it into words that I make it whole; this wholeness means that it has lost its power to hurt me; it gives me, perhaps because by doing so I take away the pain, a great delight to put the severed parts together. Perhaps this is the strongest pleasure known to me. It is the rapture I get when in writing I seem to be discovering what belongs to what; making a scene come right; making a character come together (Woolf "A Sketch of the Past" 72).

Woolf depicts the process of writing as a way of rendering the experience whole and condensing time - past, present and future - through imagery, making human life contemporary in its own historical becoming. According to Agamben ("What is the Contemporary?" 2009), we must attain to the condition that allows us to recognize a single individual's life and meaningfully connect it to the unity of a collective historical period as one that fails inevitably as fractures sever the parts from the whole, the contemporary remaining thus as remote as it is close to the observer. The poet, therefore, is the one able to suture the breaks and make sense of contemporariness even if this attempt proves ineffectual as it is ultimately unattainable if not through the suggestions of what is, in fact, present and finite though unverifiable. The historical becoming comes to be in the tension between the archeological past and the present moment, both of which converge in what Agamben in his The Signature of All Things: On Method (2008) will refer to as the future anterior, a tense that translates the time of the arché, understood as an ontological force that operates in history. Here, arché does not refer to a diachronic study of a remote past whose specific point in time can be retrieved as the departure to a chronological and teleological understanding of the present, an anterior cause that would lead to posterior consequences. Instead, arché relates to an apprehension of the past and the present in the manifold ways that time can be reassessed, reinterpreted and reimagined as it emerges as a past that will have been, something else in the potency of its becoming each time we access it.

In the essay "Craftsmanship" (1937), Woolf explores the potency of the English language as she demystifies its apparent usefulness in clearly conveying meaning. Being unfit for the task of expressing anything of use, which can only be achieved with a language of signs, words should, therefore, be submitted to a different treatment from which can arise new and fresh interpretations through new marriages within such an old language. The interesting imagery that Woolf uses to discuss the nature of words, writing and thinking seems to overlap with Agamben's to a certain extent. Woolf states that the light shed by words is as fleeting as the truth they reveal is many-sided, "flashing this way, then that" (Woolf "Craftsmanship" 90). She adds that

all we can say about them, as we peer at them over the edge of that deep, dark and only fitfully illuminated cavern in which they live - the mind 
- all we can say about them is that they seem to like people to think and to feel before they use them, but to think and to feel not about them, but about something different (Woolf "Craftsmanship" 90).

The pause we take to consider all of this is the period of gestation that can allow for light to be regenerated through darkness, darkness being here not deprivation of light, but rather its birthplace or origin. Likewise, Agamben contends that "the contemporary is he who firmly holds his gaze on his own time so as to perceive not its light, but rather its darkness" (Agamben "What is the Contemporary?" 44). The contemporary would, therefore, be the one capable of working his way through what is just apparently clear to deliberately engage with what remains obscure, unsaid, unheard, but only suggested in the lights of contemporaneity. Those who inhabit this landscape are the ones that see through the blinding lights of the century the obscurity of a sentence that faulters, of broken words, of images that, as Woolf had said earlier, "allow for the sunken meanings to remain sunken, suggested, not stated" (Woolf "Craftsmanship" 36). For this reason, Agamben ("What is the Contemporary?" 2009) argues that being a contemporary is ultimately a question of courage, because it is a task of effort that will inevitably fail to reach the present moment upon which one stands.

To illustrate his point even further, Agamben ("What is the Contemporary?" 2009) turns to the neurophysiology of vision to reflect upon the nature of darkness and how the human body responds to it. Neurophysiologists say that, when we find ourselves in a place deprived of light or when we close our eyes, a series of peripheral cells in the retina called "off-cells" are activated, which means that the particular kind of vision we understand as "darkness" is not a privative notion, but rather the product of the "off-cells" at work. Interestingly, Agamben extends this scientific analysis of human vision to his thesis on the darkness of contemporariness, now as a metaphor for the human ability to see darkness and not to blindly look for shelter in the obvious and somewhat safe clarity of one's own time. To see this darkness, therefore, is to actively try to neutralize the lights that come from an epoch to discover its obscurity as well, so inextricably intertwined they are.

Going back to the idea of "perpetual converse" as a philosophical method in Woolf's oeuvre, I would like to connect the conversation held amongst fictional critics, novelists and poets in "How It Strikes a Contemporary" with the notion of contemporariness. If Pinho (2020) helps us to reflect on the endless possibilities of engaging with what is contrary in others, whatever opposes or contradicts one's ideas, I would also like to examine the temporalities and ambiguities that are at play at Woolf's table talk. As participants manifest their opinions either in agreement or, mostly as we see throughout the essay, in disagreement with one another, it becomes apparent that the discussion of the present moment whether a contemporary work of art is any good - turns to the past as a time that provides them with examples of creativity and originality against which to be measured so as to disclose possibilities of critically assessing the achievements of the present, while contemplating possibilities in the future. Amongst due 
criticism, innuendoes and perhaps passive aggressive comments, contemporaries are embedded in the present whilst simultaneously having to inhabit the past, as recollection of literary history, and the future, as prediction of works of art to come, opposing or even contradicting one another. This allows for Woolf's polyphony to further complicate the matter so that no solid or final conclusions are made. In fact, I would argue that the ambiguities of her text enhance its conversational quality. It is through this dynamic of opposition through casual conversation that inconsistencies may surface and that room for doubt can open up possibilities of rethinking and reworking putative frameworks, leading to a critical $^{3}$ appraisal of ideas, values and approaches.

At the end of the essay, Woolf hands out what I understand to be provisional pieces of advice to the participants of the table talk ${ }^{4}$. To the poets and novelists, she recommends renouncing the hope of creating masterpieces, saying that

their poems, plays, biographies, are not books but notebooks, and Time like a good schoolmaster, will take them in his hands, point to their blots and scrawls and erasions, and tear them across; but he will not throw them into the waste-paper basket. He will keep them because other students will find them very useful. It is from notebooks of the present that the masterpieces of the future are made (Woolf "How It Strikes a Contemporary" 30).

What is at stake here is the force that impels writers to try to make sense of the many transformations the twentieth century would still undergo, breaking free from some of the constraints of the past - Woolf herself warns fellow women writers of the pressing need to kill the Angel of the House in the essay "Professions for Women" (1931), for instance - while still striving to keep up with the latest inventions and innovations that would inevitably forever change the modern rhythms of experiencing life in urban centers. The tentative bits and pieces made new from the empty spaces left by the tomes of tradition could even be said to anticipate the post-modern turn, as it questions the writer's anxiety to assert their identity through great masterpieces. Instead, what is suggested is a more collective understanding of a communal effort to feel, think and express both what is intelligible and historically constructed together with other members of the community, and what is unintelligible and can only be intuitively guessed at when one is compelled to write down and so soften the blows life gives.

Woolf's advice to critics, on the other hand, feels all the more puzzling as the essay ends with the prophetic image of Lady Hester Stanhope, who kept a horse in her stable ready for the Messiah, reminding us to "scan the horizon; see the past in relation to the future; and so prepare the way for masterpieces to come" (Woolf "How It Strikes a Contemporary" 31). When asking us to follow Lady Hester's example, Woolf gives us signs of her feminist aesthetics by making use of the female gaze to inscribe the feminine sentence into the realm of mysticism and difference. In fact, I draw this argument as I read Davi Pinho's book Imagens do feminino na obra e vida de Virginia Woolf (2015), in which he assesses the images of the feminine in Virginia Woolf's oeuvre, which serve as paradigms, signaling "an ontological break" 
(Pinho 185) that reinstates a common language to be used by writers and thinkers. Pinho affirms that "men and women need to make use of the feminine, ascribing to it another position than that of the object in [phallologocentric] language. The genuinely free human being would be in between these two languages" (Pinho 185) - the androgynous turn featured in A Room of One's Own.

In A Room of One's Own, Virginia Woolf would later more clearly develop her critique of the masculine sentence. In chapter six, she refers to a new novel by Mr. A, which, though admirable in its directness and straightforwardness, still haunted the reader as "a shadow seemed to lie across the page. It was a straight dark bar, a shadow shaped something like the letter 'I"' (Woolf A Room of One's Own 99), which would create a mist around itself so that things and others would become virtually indistinguishable, their existence made dull and perhaps inconsistent if not to consolidate the shape, color and overall presence of this letter "I". As a representative of the masculine sentence, this novel serves to illustrate a language whose words dictate the norms and the ethos of a world designed and regulated by patriarchy. The masculine sentence affirms its own validity by excluding any other form of thought and performance that does not include in its own system the values it upholds.

The masculine sentence is inclusive of that which helps to stabilize its system through exception, alienating its counterpart, what Woolf calls the feminine sentence, whose exercise is carried out through "broken words". This is an expression used by Bernard in The Waves (1931), and it anticipates what Agamben (Homo Sacer - Sovereign Power and Bare Life 1998) refers to as an example through an "exclusive inclusion", words that are tentative by nature since they do not assert an ultimate and final answer to what is complex, still unfolding and so not fixed to conform to previously established parameters. The example, already belonging to a class, functions as a paradigm, whose etymology refers to what is "shown beside" and so cannot be contained in a class. It slips and slides, no longer functioning, but rather disrupting rules and their exceptions as it exercises exclusion in that it does not adhere to traditional logic.

It is through broken words that a chasm can be occasioned in the assertiveness of the masculine sentence. However, the feminine sentence, having been historically constructed as the linguistic and performative alternative that cannot directly, univocally and undoubtedly affirm itself, folds onto its own recesses and gives hints of its inaccessibility in a world that is historically anchored in patriarchy and only recently has had its pillars succumb. Androgyny is the answer to which Woolf points as indicative of the language that can merge traces of both the masculine and the feminine sentences, disclosing the possibility of a mind that moves beyond the affirmation of sameness, while alienating anything resembling otherness. The forceful and assertive performance of the masculine sentence, which desperately needs to subjugate, is appeased by the feminine sensibility, which opens up to the alterity embodied in the other - William Shakespeare being Woolf's prime example of how this androgynous mind has already been made manifest in literary history. 
I would like to think that, even if historically Woolf was speaking directly to an audience of women when advocating for the material need of a room of one's own and 500 pounds a year, what she argues in A Room of One's Own can textually help readers today envision a reality communally constructed by men and women, reshaping human relations and refashioning ways of thinking and performing in what Rosi Braidotti calls "a nomadic becoming" in Nomadic Theory, The Portable Rosi Braidotti (2011). In fact, Braidotti's thesis is that Woolf invents a genre of her own, namely the "intensive genre of becoming", which mobilizes and actualizes different affects, concepts and percepts with which readers come in contact. "The intensive text is an experimental site, a laboratory for the new in the sense of the actualizations of experiments in becoming" (Braidotti 156). The text expands the notion of a molar subject, whose identity is solid, univocal and stable, to open up the possibilities in which new and unprecedented movements can deterritorialize and so escape predetermined coordinates as a molecular subjectivity emerges. In this context, the author is a "multiplier of virtual possibilities, through the rigorous application of the rules of composition of assemblages" (Braidotti 156), and so traditional conceptions of character construction, plot development, passing of time and narration, for instance, are reinvented to accommodate the new needs that arise. The numerous examples Braidoti gives us of both Woolf's fiction and non-fiction illumine the ways in which the Woolfian sentence can be made our contemporary in thinking of a community that resonates with the final remarks of the narrator of A Room of One's Own - "I am talking of the common life which is the real life and not of the little separate lives which we live as individuals" (Woolf $A$ Room of One's Own 113).

Perhaps if we go back to the final remarks of "The Modern Essay", the initially impenetrable phrasing of the "contemporary dilemma" seems a bit more tangible now. It feels that her contemporaries' lack of an obstinate conviction stems from a refusal to let the common language translated in the union of the masculine and the feminine sentences to conjoin the multiple possibilities engendered in an androgynous sentence. This approach to perceiving, thinking, performing and feeling goes beyond cultural expectations and sociopolitical categories, whether they be related to gender, social class, nationality or race, as it allows for the ebb and flow of the forces of life and death to disrupt established identities and the textual conventions used to express and discuss them in the specificity of their historical becoming. And yet, even if the dilemma might have become clearer to us, it does not mean it is any less of a challenge posed to critics as they stand upon the present moment whilst gazing into the horizon, trying to foresee traces of fresh and novel attempts to rearrange old patterns so as to make them new.

Scanning the horizon along with Lady Hester, we will have been able to see the endless possibilities of reassessing the past, all of which is feasible due to the persistence of the imagination to bring about a future that adds what Woolf refers to as "a supplement to history" (A Room of One's Own 45). Lady Hester's messianic time, "the time of the now" (Agamben "What is the Contemporary?" 52), puts literary history in direct contact with the present so that the future 
can allow for women writers to fulfill their potential then (as we historically recuperate texts and writers outside the canon) and now (as women have gained financial independence). Scanning the horizon entails an opening up to the totality of perception, which seeks and firmly believes it can find that which it longs for in the near future. This strategy, even if mediated by the past in a comparative approach, does not have its value fully measured by what has already been written. What is also at play is that which is unprecedented and/or deemed impossible along with what has been fully carried out - the future reevaluating the past just as the past signals paths towards the future.

\section{Acknowledgements}

This article was greatly inspired by "Virginia Woolf em diálogo: tradição e escritura", a postgraduate course taught by Professor Davi Pinho at the State University of Rio de Janeiro in 2017.

\section{Notes}

1. Also known as "Mr. Bennett and Mrs. Brown" (1924).

2. Here I evade biographical questions that could establish a female competition at the heart of Virginia Woolf's production as opposed to Molly Hite in Woolf's Ambiguities: Tonal Modernism, Narrative Strategy, Feminist Precursors (2017). Instead, I prefer to think about the method of Woolf's writing.

3. Here I believe an etymological appreciation of the Greek Kpivelv, from which the word "critique" is derived, could be helpful as it means "to separate, to discern, to delimit, to decide". A critical appraisal of ideas, values and approaches would, therefore, entail not only conversing with what opposes and contradicts but also collecting the bits and pieces of the aftermath in order to separate, discern, delimit and finally decide how they can be sutured to form a whole - perhaps even a mosaic that later could be reconfigured.

4. I would like to echo Julia Briggs's words as she was so apt to notice the pragmatism that helped shape and mobilize The Common Reader - First Series: "Woolf recognized the need to change her readers' approach if they were to cope with Mrs. Dalloway, and modernist texts more generally" (Briggs 123). Briggs (2005) suggests that one of Woolf's intentions with this publication was to educate readers and broaden their horizons, just as Roger Fry had managed to do with his book of essays, Vision and Design (1920), working to develop and extend reception of a more comprehensive and democratic take on art history.

\section{References}

Agamben, Giorgio. "What is the Contemporary?" What Is an Apparatus? and Other Essays. Stanford University Press, 2009, pp. 39-54.

Agamben, Giorgio. "Philosophical Archaeology." The Signature of All Things: on Method. Zane Books, 2009, pp. 9-34

Agamben, Giorgio. "The Logic of Sovereignty." Homo Sacer - Sovereign Power and Bare Life, Stanford University Press, 1998, pp. 15-44.

Braidotti, Rosi. "Intensive Genre and the Demise of Gender". Nomadic Theory, The Portable Rosi Braidotti, Columbia University Press, 2011, pp. 150-169.

Briggs, Julia. “A Woman Connects”. An Inner Life, Harcourt, 2005, pp. 109-129. 
Fry, Roger. Vision and Design. Dover Publications, 2011.

Goldman, Jane. Modernism, 1910-1945, Image to Apocalypse. Palgrave MacMillan, 2004.

Hite, Molly. Woolf's Ambiguities: Tonal Modernism, Narrative Strategy, Feminist Precursors. Cornell University Press, 2017.

Lee, Hermione. "Virginia Woolf's Essays." The Cambridge Companion to Virginia Woolf, edited by Susan Sellers, Cambridge University Press, 2010, pp. 89-106.

McNeillie, Andrew. "Introduction." The Common Reader - Volume I, written by Virginia Woolf, Vintage, 2003, pp. vii-xii.

Pinho, Davi. “A conversa como um 'método' filosófico em Virginia Woolf." Conversas com Virginia Woolf, edited by Davi Pinho, Maria Oliveira and Nícea Nogueira, Ape'ku, 2020, pp. 11-31.

Pinho, Davi. Imagens do feminino na obra e na vida de Virginia Woolf. Appris, 2015.

Woolf, Virginia. A Room of One's Own. Wordsworth Classics, 2012.

Woolf, Virginia. "A Sketch of the Past." Moments of Being, Harcourt Inc, 1985, pp. 61-159.

Woolf, Virginia. "Character in Fiction." Selected Essays, Oxford University Press, 2009, pp. 37-54.

Woolf, Virginia. "Craftsmanship." Selected Essays, Oxford Classics, 2009, pp. 85-91.

Woolf, Virginia. "How it Strikes a Contemporary". Selected Essays, Oxford Classics, 2009, pp. 23-31.

Woolf, Virginia. The Diary of Virginia Woolf, edited by Anne Olivier Bell, Penguin Books, 1979-1985.

Woolf, Virginia. "The Modern Essay". Selected Essays, Oxford Classics, 2009, pp. 1322.

Woolf, Virginia. The Waves. Oxford Classics, 2015.

Recebido em: 09/06/2020

Aceito em: 13/08/2020 